\title{
CYP2D6*18 Allele
}

National Cancer Institute

\section{Source}

National Cancer Institute. CYP2D6*18 Allele. NCI Thesaurus. Code C46050.

Human CYP2D6*18 allele is located in the vicinity of $22 \mathrm{q} 13.1$ and is approximately $4 \mathrm{~kb}$ in length. This allele, a variant form of the CYP2D6 wild-type allele, encodes cytochrome P450 2D6*18 protein. The CYP2D6*18 allele exhibits a nine nucleotide insertion (g.4125insGT GCCCACT) in exon 9. This alteration increased the $\mathrm{Km}$ value of the cytochrome P450 2D6*18 protein toward bufuralol, resulting in decreased enzymatic activity. 